\title{
Individual transferable quotas and conservation: a critical assessment
}

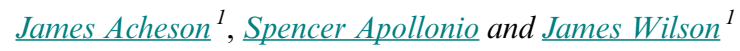

\begin{abstract}
Individual transferable quotas (ITQs) have become a popular management tool for fisheries. They have been promoted in some quarters and seriously criticized in others because of their social and economic impacts. A more serious problem is that ITQs provide exclusive access to public resources presumably in return for some public benefit, namely conservation; however, in a high percentage of cases they do not conserve fish stocks. In this article, we focus on the reasons that ITQs do not conserve stocks. We point to a number of phenomena identified in the literature as affecting stocks of fish, including problems with total allowable catch (TAC), ecological hierarchy theory, $r$ and $K$ species, the Allee effect, scale and metapopulation structure, the need to have selective gear, and the continuation of roving bandit incentives. Despite their growing popularity with managers, ITQs do not solve any of these problems. We argue there may be better ways to manage. One possibility is what we call parametric management.
\end{abstract}

Key Words: fisheries management; individual transferable quota; ITQs; quota management

\section{INTRODUCTION AND BACKGROUND}

There is increasing evidence that efforts to manage marine fisheries have generally failed. After decades of attempts at management, over $63 \%$ of marine species are considered overfished and require "rebuilding" (Worm et al. 2009:578); some are dangerously depleted. Fisheries managers have begun a serious search for alternative types of management (Copes and Charles 2004). One of the new management techniques that has become increasingly popular is individual transferable quotas (ITQs), ${ }^{[1]}$ a type of market-based management system that give fishermen quasi-private property rights over the resource (McCay et al. 1995, McCay 2004, Squires et al. 1998). Specifically, ITQs are permits given by a government to individuals to allow these individual to "catch or transfer a certain portion of total allowable catch (TAC)" (Pinkerton and Edwards 2009:707).

In this article we focus on the relative success of ITQ management. Despite their growing popularity, there are a number of reasons that ITQs have limited success in conserving stocks. We discuss several well-accepted concepts about factors that control stock sizes in an attempt to explain the problems with ITQ management.

Anderson (2000) points out there are three aspects of ITQ systems: (1) The basic management tool is a total allowable catch (TAC) for a given species usually over a broad range, established by government scientists. (2) Quasi-ownership rights are held by individuals who may use them at any time. (3) The rights are transferable so that they may be bought, sold, or transferred to anyone who has the cash to buy a permit and quota.

ITQs are the creation of economists. Most of the discussion focuses on the pros and cons of ITQs' social and economic effects. In this article we focus primarily on an important topic that has received less attention: What effect does the imposition of ITQs have on conservation of fish stocks?

ITQs are a relatively new management tool. They were first proposed by Christy (1973); see also McCay (2004). The first ITQ systems were put into effect in Iceland, New Zealand, the Netherlands, and later in Canada (Arnason 2005, Chu 2009). This management system is expanding rapidly (McCay et al. 1995,
Yandle and Dewees 2008). Chu (2009:217) says that "eighteen countries currently use ITQs to manage several hundred stocks of at least 249 species." Costello et al. (2010) mention 150 ITQ programs.

ITQ management is controversial, with proponents and opponents disagreeing on many points. Many authors aver that ITQs increase private and public efficiency. According to proponents, ITQs give fishermen some property rights over fish stocks, which goes a long way toward addressing problems of overexploitation, overcapitalization, and inefficient use of fish stocks (Arnason 2000, 2005, Huggins 2011, Olson 2011). Holland (2000:141) says that "economists have long advocated ITQs as a means of internalizing stock externalities." If an owner has complete and secure property rights, he or she obtains all of the returns earned by that property; and the owner has to assume the costs that his or her actions do to the property of others. Because the owner does not have to share the returns from the property with others, there is an incentive to invest in the property and avoid squandering it (Arnason 2000, 2012). ITQs are said to promote conservation and efficiency. They also promote sustainability by "giving people an incentive to use a low discount rate,"i.e., postpone immediate rewards to get even greater rewards in the future (Munro et al. 1998:12). Huggins (2011:8) says more secure ownership rights that come with ITQs give "fishers an incentive to reduce overfishing and avoid sensitive spawning areas to promote stock recovery."

When ITQs are established, quotas are bought by the most efficient boat owners while the less efficient owners either curtail fishing activities or leave the industry altogether. The result is that the same catch is shared by fewer boats, leading to an increase in catch per vessel, fewer owners, increased profits, and reduction in overcapitalization (Sanchirico and Newell 2003, Sumaila 2010). This occurs without cost to the government. In addition, by giving fishermen an assured right to catch a certain quota of fish, ITQs end the race for fish. Each year this results in harvesting fish over a longer period of time; it also avoids gluts in the market and promotes safety by permitting fishermen to avoid fishing in dangerous weather (Anderson 2000, Huggins 2011). 
Some authors are quite laudatory about the effects of ITQs on fisheries, mentioning a long list of positive attributes ranging from increased prices to fishermen, an increase in fish quality, and more flexibility for fishermen, to a reduction in costs, fewer instances where fish targets are exceeded, and less cheating (Leal et al. 2006; see also Holland 2000). Moreover, in a number of cases, but not all, they do conserve fish stocks.

However, a number of analysts point out long lists of costs and problems that come with ITQs. The list of critics is a long one: Salz (1996), Copes (2000), Wingard (2000), Bromley (2009), Ecotrust Canada (2009), Gibbs (2010), Cabral and Aliño (2011), Olson (2011), and Soliman (2014).

In an ITQ system, opportunities to cheat are ever present (Anderson 2000, Criddle and Macinko 2000, Copes and Charles 2004). Quotas are often exceeded ("quota busting"), and there are numerous instances of "high grading," i.e., culling one's catch and keeping the large, high-quality marketable fish and discarding less desirable fish. Enforcing quotas means keeping accurate records on landings of all fish by boat, which adds to enforcement costs.

ITQs reduce the number of boats in the fleet and can increase unemployment (Yandle and Dewees 2008, Olson 2011). In addition, the imposition of ITQs typically results in the fleet being concentrated in the hands of those who can afford to purchase quota from others, resulting in economic concentration and market power (Bernier 1997, Criddle and Macinko 2000, Eythórsson 2000, Olson 2011). It also can result in a loss of the small-boat fleet and a concentration of boats and processing facilities in some ports, with a decline in maritime activity in other ports (Eythórsson 2000). The costs often fall on the poor who lack easy access to capital markets (Olson 2011). Perhaps most important, ITQs can lead to increases in social class distinctions and severe problems with equity and social justice (McCay et al. 1995, Palsson and Pétursdóttir 1997, Copes and Charles 2004, Sumaila 2010).

There is also evidence that leasing of quota can reduce the economic benefit to society (Pinkerton and Edwards 2009) because it introduces inefficiencies. More important, ITQs make a gift of part of the public domain to fishing firms (Bromley 2009). Bromley (2009) deserves special note. He criticizes ITQs not only for being ineffective and costly, but also because they are based on highly flawed economic analyses. Bromley's point of view is quite close to our own save for the fact that he does not emphasize biological outcomes.

\section{EFFECTS OF ITQS ON FISH STOCKS}

Although there are not a large number of studies on the effects of ITQs on stocks, the best evidence strongly suggests the effects are mixed. Chu (2009) points out that in a study of 20 stocks where biomass changes were analyzed, there was improvement in 12 stocks after the advent of an ITQ program. The other eight $(40 \%)$ continued to decline. She concludes that ITQs can be an effective component of management in many cases, but it is no guarantee of success. The same lack of consistent results was reported by Branch (2009), who analyzed the effect of ITQs as reported in 227 peer-reviewed papers. He points out that $42 \%$ do not mention "ecological effects while the majority of the rest include anecdotal evidence only" (Branch 2009:40-41). Thirty- five papers or $15 \%$ of the total reported on the biological effects of ITQs. The results were mixed, with $60 \%$ of these reporting a positive effect, while $23 \%$ reported a negative effect, and another $14 \%$ reported a mixed effect. (Three papers did not address the biological effects.) Essington (2010) assessed the effect of implementing catch shares on certain indicators of conservation, including biomass, fishing effort, and discards. With the exception of a decline in discard rate, he is unable to see any significant change in these indicators following implementation of ITQs. Costello et al. (2008) report the most positive results. They used a statistical model to study ITQs and concluded ITQs do help prevent the collapse of fisheries. Confounding the results of Costello et al. (2008) is that ITQs are often implemented after stocks have crashed or shown serious signs of depletion. Subsequent (after the ITQ) crashes and/or depletions might not be possible.

Others are more dubious about the conservation effects of ITQs. In fact many authors say that ITQs have little effect on stocks (e.g., Holland 2000, Clay et al. 2010, Essington et al. 2012). Moreover, Nowlis and Van Bentham (2012) are critical of the positive studies because the increases in stocks are not likely due to ITQs alone (see also Bromley 2009).

Some believe that many stocks are in a state of recovery because of the imposition of quotas. However, the studies by Branch (2009) and Chu (2009) do not support this conclusion. Moreover, we cannot find a long list of recovered stocks. We believe the picture is mixed. Hilborn and Hilborn (2012:xvi) summarize the situation well when they say, "There are places that have been severely overfished, and others that have not. Some management agencies have reduced fishing pressure and stocks are recovering, while elsewhere fishing pressure has been left too high and overfishing continues." ITQs have done little to change this overall assessment.

To be sure, we are defining management success solely in terms of the effects on stocks. This is a narrow definition. In the U.S., for example, federal fisheries managers are required by the Sustainable Fisheries Act to consider a number of factors in promulgating rules, including economic effects on communities. Saving the fish, however, is primary. As Bromley (2009:286) points out, "the job of fisheries managers is to protect fish stocksnot to try to maintain the profits of the fleet." We agree.

In summary, despite the fact that ITQs are spreading rapidly, there is every reason to be skeptical about their effectiveness as a conservation device (see also Thébaud et al. 2012). In our view this is the major problem with ITQ management. ITQs may be highly successful in ending the race for fish and increase revenues to fishermen, but their limited success in improving stocks is a serious indictment.

\section{PROBLEMS WITH ITQS AS A MANAGEMENT TOOL}

In our view, ITQs fail to address many factors scientists have identified as influencing stock sizes. Given these failings, it is scarcely surprising that ITQs do not perform well as a management tool.

\section{Efficiency and industry concentration}

As we noted earlier, according to proponents one of the virtues of ITQs is the increase in efficiency because quotas can be traded 
and end up in the hands of the most efficient boat owners, resulting in fewer boats, increase in catches per vessel, higher profit, and lower labor costs (Wingard 2000, Soliman 2014). The advocates of ITQs see this consolidation in the industry as highly desirable from an economic point of view. We might point out that the economic benefits claimed for many ITQs are simply the higher profits and lower capital costs of the remaining fishermen. Any market will show these effects if competition is restricted. At a minimum, the restricted competition created by an ITQ program is good public policy only if it produces a public benefit in the form of healthier stocks and larger or more sustainable catches.

Another public policy aspect of ITQs concerns "regulatory capture." This is not a problem unique to ITQs or fisheries. It is a problem that arises when any regulatory process is dominated by the individuals and firms that are presumably being regulated. A good relationship between regulators and those regulated is often desirable, but when the outcome of regulation is inefficient and unfair, poor regulatory capture may lock public policy into undesirable outcomes. In fisheries, representation is costly, and usually only those with a direct financial interest in the outcome can afford to participate. In these instances, ITQs restrict access to the public wealth and reduce economic opportunities. In the absence of conservation, ITQs are little more than a way to create privilege and inequality of opportunity.

\section{Metapopulations, technology, and roving bandits}

ITQs and other quota-based approaches to management try to protect growth (yield per recruit) and spawning potential. Usually quotas are applied at a broad scale, often using boundaries that reflect knowledge of population structure in the 1970s. Since the 1970s, however, it has become clear that many, perhaps most, vertebrate fish have what is characterized as metapopulation structures, that is, local populations that are adapted to particular places for spawning but also for other points in their life cycle. In these instances broad-scale quotas do not protect the local components of the populations. When the profitability of one subpopulation is greater than another, fishermen will preferentially harvest the more profitable subpopulations. Over time this tends to drive all populations toward similar levels of profitability. If those subpopulations are characterized by minimum viable sizes, sooner or later variation may cause one subpopulation, then the next and the next to fall below the threshold. In short, quotas that are not matched to stock size or range exacerbate overexploitation by failing to protect the local ecological structure. Over the long run, the use of ITQs can lead to disorganization of the stock, and ecological disaster.

If ITQs are to work, they need to be applied at the right scale (Wilson 2006). For example, problems with northern cod (Gadus morhua) and the other fisheries of Newfoundland and Labrador appear to stem from serial extirpation of metapopulations by boats using roving-bandit strategies and the use of ever larger boats with more sophisticated technology (Rose 2007, Hayden et al. 2015). Typically, fishermen exploit concentrations of fish near shore, and when those are depleted or extirpated, they get larger and more sophisticated boats to exploit fish concentrations further offshore. When those are used up, they get still larger boats and move still further offshore where the same sequence occurs (Swartz et al. 2010, Bolster 2012). This dynamic of depletion and extirpation generates strong incentives that ITQs do little to abate. In short, ITQs can lead to very perverse consequences.
Management is aimed at controlling effort over the entire range of the stock so that limits are framed to control average exploitation. But fleets are not exploiting an entire range. The solution from this perspective is (1) to control roving-bandit behavior by permitting boats to fish only in certain areas and (2) to match effort to the size of subpopulations. ITQs do neither.

\section{Selective gear}

ITQs ignore the critical problem of gear selectivity. Several observers of fisheries have long called for more selective gear. The fisheries techniques used to capture fin fish in First World countries are particularly problematic. The most popular gear is the otter trawl, which inevitably results in taking small and reproductive-sized fish. Its use also results in a substantial bycatch. The heavy trawl doors that hold open the net cause substantial damage to the ocean bottom. Not only does the use of trawls result in high mortality on fish caught, but there is substantial evidence that "trawling has reduced the growth rates of some species and some species may not recover in trawled habitats" (Hilborn and Hilborn 2012:101).

In addition, there are problems of increases in by-catches because several different fish species are regularly caught at the same time in the same net. These practices result in an increase in mortality and a huge waste of fish (Squires et al. 1998, Criddle and Macinko 2000, McCay 2004, Yandle and Dewees 2008, Pinkerton and Edwards 2009).

However, it is difficult to advocate the complete abolition of trawling gear because some species can only be harvested by this gear, e.g., Atlantic scallops (Placopecten magellanicus), flatfish. Some areas have been trawled for long periods and still produce a substantial amount of fish, and some trawl fisheries are quite successful, including the Pacific pollock (Gadus chalcogrammus) fishery.

Given the damage to stocks and habitats done by otter trawls, it would be highly desirable to develop selective fishing gear. Although virtually every environmental group has urged substituting more selective gear in place of otter trawling, little has been done to produce such fish capture techniques. Apollonio and Dykstra (2008) point out that more selective fishing gear might be developed by using promising new electronic technologies, e.g., sound and light to attract fish (Spilhaus 1963).

Some of the problems caused by the use of unselective gear can be alleviated by a variety of strategies. Existing trawling gear can be made more selective by using larger mesh sizes and excluder devices which would allow some more small fish to escape. However, this does nothing to conserve the more valuable large females. Gillnets and long lines are more selective, but have their own problems (Apollonio and Dykstra 2008). More reliance might be placed on fish-trap technology, but they can only be used in shallow waters. The fishing gear used in Third World countries, emphasizing fish traps, weirs, and spears, is more selective, but probably not applicable to industrial fisheries in general. This likely means that unselective gear is going to be widely used for a long time.

We believe it is difficult to overestimate the problem of unselective fishing gear. If we were empowered to pass one rule to increase the probability of ending overexploitation, it would be to replace the otter trawl with selective gear. This cannot happen quickly given the current environment, but it is still a desirable goal. 
Maximum sustainable yield [MSY] and stock-recruitment models The basis of scientific management, including ITQs, is stockrecruitment models, which are concerned with the populations of stocks of fish. The central idea is that the long-term abundance or sustainability of a species is linked to the spawning stock size, which in turn is strongly influenced by the amount of exploitive effort on that stock (Beverton and Holt 1957). In theory, the relationship between stock size and fishing effort can be described mathematically. At low levels of effort, there is a large breeding stock and a high population. At high levels of effort, the breeding stock is reduced, producing low recruitment (Cushing 1977, Wieland 1992). If effort continues at very high levels, stock levels and yields will be very low. (Stock-recruitment models have been parodied as saying that "more mommies means more babies.") The objective of conventional management is to limit effort to the point where maximum economic yield occurs or where maximum sustainable yield (MSY) results. In either case, fishing effort can be limited by rules designed to lower mortality on fish or directly by a quota. ITQs, of course, use a quota.

In most cases, there is little empirical evidence that stockrecruitment models work. In some cases such as Maine lobster (Homarus americanus), increase in effort has not reduced recruitment (Acheson and Steneck 1997). In other cases, large year classes of fish were produced by small parent stocks. It is true that in both World War I and World War II when fishing effort went down, stocks went up. But these are rare cases. Controlling effort was also correlated with increases in stocks in both the sea bass industry and the salmon fisheries in Alaska and the Fraser River, but many factors other than effort could explain the changes in stock sizes in these cases.

As early as 1977, scientists argued that MSY was a flawed concept (see also Finley 2011). Even Beverton (1998), a pioneering population dynamicist, complains that little scientific evidence has been put forward to validate the idea.

The MSY concept can be linked to several different kinds of problems of management. First, stock-recruitment models lead unerringly to policies designed to regulate the amount of fish taken. There is no concern with the stage of the life cycle that the fish are in. According to proponents of the model, any ton of fish is worth the same as any other ton regardless of the composition of the catch. However, there is evidence that fish caught at one part of their life cycle can have a different effect on stock size and recruitment than fish caught at another stage. It is important to maintain the breeding stock, and taking large numbers of gravid females can have a devastating effect (Berkeley et al. 2004).

More important, stock-recruitment models define the goals of management in terms of controlling effort at a point where MSY is achieved. To achieve this end, fishing effort cannot be permitted to exceed the MSY level. In ITQ management this is done by setting a quota. The problem is that it is virtually impossible to set a quota accurately (Brewer 2011). The number of variables involved is so large and the feedback mechanisms between them are so complicated that a great deal of fine-grained, continuously updated information would be required to predict changes in stocks as effort alters. Population dynamics expert Yong Chen recently remarked (personal communication) that predicted stock sizes are almost always wrong by a large amount and are frequently even of the wrong sign, i.e., stocks rose when they were expected to fall and vice versa. Longhurst (2010:13) phrases the problem forcefully in speaking about the "general unreliability of stock-assessment data." He goes on to say "it is hard to overemphasize the extent of the gap between the assumptions often used in establishing allowable catches and reality" (Longhurst 2010:210). In this respect, the problem with ITQs is general to all management systems depending on a quota.

As a general rule, biological and economic concerns cannot be separated if good policy is to be produced. If biological policy is based on the assumption that it is possible to predict and set accurate quotas (as standard theory assumes), then economic policy based on that assumption is bound to be less than optimal.

\section{$r$ and $K$ selection}

ITQs do not take account of inherent biological realities that have important implications for management. One of the most important concepts is that of $r$-and $K$-selected species, a concept that describes the range of diverse species based on important biological characteristics (Pianka 1970, Adams 1980). The terms $r$ and $K$ selection are derived from the numerical parameters of the standard population-growth equation that describes the pattern of growth of many species. The $r$ refers to the logarithmic phase or rapid growth period of any increasing population. The $K$ refers to the carrying capacity of the environment, i.e., when a population reaches its asymptote. $\mathrm{R}$ species are adapted to rapid growth or decline and thus exhibit substantial fluctuations in numbers. $K$ species are inherently slow growing, long lived, and have relatively stable populations. The two kinds of species have different life-history characteristics, including different age structures, age of maturity, growth rates, fecundity, numbers of reproductive periods, length of life, relative sizes, spatial heterogeneity, and responsiveness to physical and biological perturbations (Adams 1980, Apollonio and Dykstra 2008).

Populations of $r$-selected species are inherently variable because they are controlled by factors in the environment such as water temperature, upwelling, and currents, factors well beyond the control of managers. These species exhibit unmanageable fluctuations and possible population crashes. Fishing effort has only a secondary effect on their populations. The concept of MSY has no relevance. Such species are not good candidates for management.

$K$-selected species, by way of contrast, with their long age structure, are inherently stable, but particularly susceptible to overfishing and vulnerable to forces that management can influence, including gear type and locations and seasons when fishing is allowed.

Yellowtail flounder (Limanda ferruginea) are an $r$-selected species (Apollonio and Dykstra 2008). For many years the species has exhibited great variability in numbers as a result of temperature variations (Sissenwine 1974). Stringent management efforts over more than 20 years failed to stabilize or achieve a hypothetical MSY in that boom or bust fishery (Apollonio and Dykstra 2008).

If a $K$ species is put under enough fishing pressure, older fish are removed from the population and both the number of year classes and the age of maturity can be reduced. In such cases, these $K$ selected species can act like r-selected species, with all that indicates for exaggerated variations in new year-classes and population numbers. There can be unmanageable fluctuations in 
population and possible population crashes. Thus, a population of heavily fished species is younger and less manageable than a population of the same species with higher proportions of older year classes. Quota management, including ITQs, is based on the assumption that all biomasses are equivalent, that a ton of oneyear-old fish is equivalent to a ton of five-year-old fish with large numbers of gravid females. The effect of fishing pressure on these two kinds of populations can be very different, and that is not recognized by current management. To be sure, ITQS can be combined with other management rules to protect juveniles and older fish, but ITQs, in and of themselves, do not do this.

\section{More biological factors: age structure and Allee effect}

Frank and Brickman (2000) point out that overfished stocks often do not rebound fast if at all. They suggest that the Allee effect is responsible for this phenomenon. That is, at low population levels there are certain biological and physiological changes that reduce reproduction. In stocks with small populations, fish may "have difficulty in finding a mate, there can be breakdowns in social structure and migration patterns, difficulty in fending off predators" (Frank and Brickman 2000:514).

Even more important, there is increasing evidence that maintaining age structure is as important in preserving stocks as is spawning biomass. Total reproductive biomass may not be the critical element in maintaining spawning potential because only a small fraction of spawners contribute to a new age class. The fish that are most essential to maintaining the population are "older, larger females," especially those that produce eggs in the right place and time (Berkeley et al. 2004:23). Fishing generally targets larger and older fish, exactly those needed to maintain the population. Quotas and TACs restrict fishermen to taking a certain amount of fish, regardless of size or reproductive status. This means that stock assessments do not give an adequate assessment of the real spawning potential of stocks (Armstrong and Sumaila 2001, Berkeley et al. 2004).

ITQs do nothing to address the problems posed by the Allee effect or the need to conserve age structure. As a practical matter, it is always difficult to conserve older reproductive fish, but we are convinced that this must be done where it is possible because failure to conserve breeding stock is a major flaw in traditional fishery management efforts.

\section{Hierarchy concept}

Hierarchy concept (Allen and Starr 1982, O’Neill et al. 1986) is a well-worked-out concept about complex ecological systems that has relevance to fish population dynamics. If this concept is applied to fisheries, it gives a different view of the goals of management and how management must proceed than standard stock-recruitment models. Hierarchy concept includes the fundamental observation that ecosystems are structured and function by different rates of processes within systems, and that those rates are hierarchically arranged. (It is important to recognize that the hierarchy is composed of rates of processes, not of structures.) At the top of the hierarchy, the rates are slower; at the bottom of the hierarchy, the rates are faster. The slower rates constrain the dynamics of processes with higher rates. The higher, slower rates prevail over more space than lower, faster rates; thus lower levels cannot escape the constraints of the higher levels. In natural systems such rates include rates of birth, growth, spawning, and mortality. In exploited fisheries, such rates would also include rates of capital investment or application of technologies and increase in fisheries efficiency.

The structure in such hierarchical systems arises from the constraints of higher, slower rates upon the lower, faster rates. For example, whales constrain the growth rates of Antarctic krill (Euphausia superba) and other species with faster spawning and reproduction rates than whales. If krill are not constrained, their growth rates lead to population explosions and dramatic fluctuations in populations. Cod present another example. In cod, older, larger, cannibalistic fish constrain the growth and reproduction of younger year classes. The concept says that the constraints of higher levels must be maintained if the system is to be reasonably stable, predictable, and in the case of fisheries, manageable.

Slower and more stable dynamics are more amenable to management than the faster and less predictable dynamics of lower levels. If management and conservation of the higher constraints on a system are effective, then the dynamics of lower levels will be naturally constrained and may be ignored, that is to say, they may vary within limits set by the natural evolution of their systems. For example, one constraint on cod is the existence of older, larger cod. MSY assumes that removal of these larger fish will result in younger fish growing more rapidly. The hierarchy concept theory and experience, however, show that removal of larger, older cod does not result in a robust, stable population of smaller cod, but a population that exhibits increasing oscillations.

What constraints control the population of fish? There are several possibilities depending on the species and the environment of fishing. For cod, one constraint can be older, larger fish, but a second can be the guild (a set of species that competes with each other for food and resources and inhabits the same ecological niche) to which cod belong, and a third can be the economic processes governing the actions of the fleet that targets cod. Removal of any of these constraints can have effects on cod populations.

One of the axioms of the hierarchy concept is that the evolution of systems integrates the function of lower levels into new functions of higher levels. The evolution of schools, for example, added to the dynamics of fish in ways that make behavior more stable and predictable. A guild represents another example of higher level of organization. It too acts as a constraint on the behavior of fish at a lower level. If something occurs to destroy schools or guilds, then disintegration of the community of fish may result, with all that says about changing the constraints that control the populations of species at a lower level.

ITQ management does not provide the constraints that are essential to effective fisheries management. Quotas are applied to the target species, which means that management is not applied to the higher level constraints controlling the population of those target species. Allen and Starr (1982) make clear that the significant or functional constraints operating on a species of particular interest (a target species) are of a slower rate and of broader scale than the target species. The constraint may be a guild of species using a resource of common interest to a species in the guild. In this sense, fishing on "underutilized species" is not good policy. The constraint could be a keystone species, or it could be the rate of investment in the species. A hierarchical constraint 
of particular relevance to a fishery is the managers' objective for management of the fishery (Apollonio 2002). Management should focus on preserving the constraints that affect the dynamics of the species of interest. The hierarchical concept makes clear that if naturally evolving constraints are not preserved, the structure of the ecosystem is disrupted and these components may fluctuate in unmanageable fashion.

\section{SUMMARY}

ITQs do not address many of the problems that need to be solved if fish stocks are to be made sustainable. First, for ITQs to be effective, the proper quota must be set (Walters and Pearce 1996). This means that the TAC must be correctly ascertained. There are problems in setting TACs. Moreover, there is little evidence that fishing effort can be linked to stock size.

Second, ITQs do little to promote conservation (Pauly 1996). To be sure, ITQs are supposed to give fishermen an incentive to conserve by guaranteeing them a fixed catch. However, they do not give secure, complete ownership rights at the right scale, and they do not do away with the problem of regulatory capture. These aspects of ITQs reduce the incentive for fishermen to conserve for the long-run benefit of the resource. ITQ systems are also plagued by high grading and quota busting, practices that can only be controlled by expensive monitoring and enforcement (Copes and Charles 2004).

Third, ITQs do nothing to ensure survival of the right species at the right times and in the right places. That is, ITQs do not help conserve the $K$ species; they do nothing to conserve older female fish that are essential to recruitment; they do not prevent the tendency to extirpate subpopulations; and they do not prevent roving-bandit behavior. Given that ITQs do not approach or solve so many phenomena that many fisheries scientists say reduce stock size, it is little wonder that the imposition of ITQs does nothing to conserve stocks in so many cases.

In addition to problems concerning conservation, ITQs raise two other policy problems. First, biological models cannot be divorced from policy and economic issues. Quota management, including ITQs, is based on the flawed assumption that populations can be predicted and controlled. An economic policy that is predicated on that assumption cannot be optimal. Second, ITQs convey part of the public domain to fishermen with no return to the public in the form of conservation.

\section{HOW SHOULD FISHERIES BE MANAGED?}

We have pointed out that traditional fisheries management suffers from a variety of problems, ranging from lack of selective gear, lack of recognition of the possibilities in considering the hierarchical concept, ignoring scale problems and the difference between $r$ and $K$ species, and failure to control roving bandit behavior. Addressing any of these problems could improve management. However we believe that managers need to consider far more drastic measures.

Given the serious social problems inherent in ITQ management and that ITQs do not conserve fish in about half the cases, we suggest abandoning the use of ITQs in favor of rules governing how, when, and where fishing is allowed. This approach, which we have called parametric management in other publications, has much to recommend it (Acheson and Wilson 1996). In stark contrast to stock-recruitment models, this approach to management assumes that stocks are complex and may change unpredictably within environmental parameters. As long as such environmental parameters are maintained, e.g., migration, spawning potential, habitats, and growth rates, stocks may fluctuate rapidly and unpredictably, but only within certain limits (Apollonio 2002).

Parametric management attempts to preserve basic biological processes rather than limit the amount of fish that can be taken. Parametric rules limit where fishing is allowed, when fishing can take place, and how fishing will be done, i.e., techniques. Traditional fisheries management systems in the Third World use these kinds of rules; there are no instances where traditional societies use quotas. These management systems have maintained fisheries in those societies for long periods of time (see Fig. 3 in Acheson and Wilson 1996).

Parametric management rules are also used in the Maine lobster fishery where catches have been at historic highs for more than 20 years (Acheson 2003). Lobster management has long been based on rules designed to conserve large reproductive-sized lobsters by using rules prohibiting taking: egged lobsters, lobsters over 5 inches on the carapace, and V-notched lobsters, which have had eggs in the past. It is also illegal to take lobsters under $3 \frac{114}{4}$ inches, a rule designed to protect juvenile lobsters. In Maine it is also illegal to use anything but traps, which are highly selective gear. Using traps makes it possible to remove lobsters that cannot be kept, i.e., oversized, undersized, or egged lobsters, and put them overboard where they survive. It is illegal to use nets to take lobsters because nets are unselective and damage a large percentage of the lobsters caught (Acheson 2003). The lobster fishery is not without its problems. It uses an enormous amount of herring as bait; the vertical lines on traps present a danger to the protected right whale population; and the cost of bait and fuel has increased to the point where the income of many lobster fishermen has been greatly reduced. But the fishery is certainly successful in sustaining and enhancing the lobster population using parametric-style rules.

Parametric management is made even more effective when it is coupled with bottoms-up management where rules are developed by user groups themselves. Resource users do not generate rules they feel are ineffective and inefficient. This is one of the reasons that lobster management works well. The industry lobbied for the rules because a large faction believed they would conserve the lobster stocks and were scientifically sound. As a result, they are willing to help enforce those rules (Acheson 2003). As a general rule, parametric management rules must be adequately enforced if they are to be effective. This is likely to occur if there is a strong civic culture causing fishermen to obey the rules themselves and to sanction violators.

Parametric management has many advantages. There is no problem calculating MSY because the goal of management is not to limit the number of fish taken. Rules on how, when, and where to fish are easier to enforce. It is relatively easier, for example, to enforce a rule forbidding fishing at a certain season or in a specific place or using forbidden gear than it is to enforce a quota, which needs an elaborate accounting and monitoring system. With parametric rules, crimes such as quota busting and high grading, the bane of ITQ systems, do not exist. Rules limiting when and 
where fishing can take place can also help eliminate roving bandits and help protect migration routes and nursery grounds. Rules mandating the use of selective gear make it possible to release certain sizes and species of fish. Such rules would help to protect $K$ species, maintain age structure, and protect reproductive stock.

Abolishing ITQs would serve still another function, namely, it would end making a gift of publicly owned resources to private individuals. Once the TAC is allocated, the fish resources belong to ITQ owners, and the government has no right to insist on additional payments from the fishermen who own the quota. ITQs, in the words of Bromley (2009), cheat the rightful owners, the public.

None of this is to suggest that parametric management would be easy. Managing groundfish, for example, by rules on how, when, and where fishing is done would mean developing more selective gear, e.g., doing away with the otter trawl, and having rules to protect breeding and nursery grounds, which would likely mean closing fishing in certain areas and places to fishing for sizeable periods of time. It would also mean conserving an adequate amount of forage fish, e.g., herring. One would also have to ensure survival of large reproductive fish, and we see no easy way to do this because fish of different sizes are mixed together. In addition, there is still a problem of how to compensate the public for use of a public resource. Gear taxes and landings fees are possible solutions. Of course if the fishery improves, there would be more firms and fishermen to pay income taxes. Still, it would likely be difficult to generate an efficient institution to ensure the public is paid for fish caught under a parametric management plan. Nevertheless, we are convinced that parametric management has enough to recommend it that it should be considered as a management option for many fisheries. ${ }^{[2]}$

${ }^{[1]}$ The study of quota management systems in fisheries is confused by the variety of terms used to describe variants on quota management. If the quota is allocated to an individual and can be transferred, it is generally called an "individual transferable quota" (ITQ) or "individual fisheries quota" (IFQ). If the quota is attached to a boat, it is called an "individual vessel quota." If rights to the quota may not be transferred, it may be called an "individual quota." If rights are given to corporations, they are called "community development grants;" if allocated to communities, they may be called "community development quotas." When rights to the fish in a specific geographic area are allocated, they are called "territorial use rights in fisheries" (TURFS). "Cooperatives" are groups allocated a quota, which are then empowered to decide how to divide the quota amongst themselves. "Sectors" are a group quota allocated to a set of fishermen who are then empowered to divide the quota and manage the fishery (Branch 2009). In this article we use the term ITQ, but what we have to say holds true for all variants on quota management.

${ }^{\text {[2] }}$ Parametric management does not preclude the use of input controls, e.g., days at sea, but it must include other measures as well if it is to succeed in preserving fish in vulnerable parts of their lifecycle.
Responses to this article can be read online at: http://www.ecologyandsociety.org/issues/responses. $\mathrm{php} / 7912$

\section{Acknowledgments:}

Thanks is due to Ann Acheson, who edited and proofread several drafts of this article, and to all of the scientists and social scientists whose work on ITQ management served as a foundation for our analysis.

\section{LITERATURE CITED}

Acheson, J. M. 2003. Capturing the commons. University Press of New England, Hanover, New Hampshire, USA.

Acheson, J. M., and R. S. Steneck. 1997. Bust and then boom in the Maine lobster industry: perspectives of fishers and biologists. North American Journal of Fisheries Management 17(4):826-847. http://dx.doi.org/10.1577/1548-8675(1997)017<0826:batbit>2.3.co:2

Acheson, J. M., and J. A. Wilson. 1996. Order out of chaos: the case for parametric management of fisheries. American Anthropologist 98(3):579-594. http://dx.doi.org/10.1525/ aa.1996.98.3.02a00110

Adams, P. B. 1980. Life history patterns in marine fishes and their consequences for fisheries management. Fishery Bulletin 78:1-12.

Allen, T. F. H., and T. B. Starr. 1982. Hierarchy: perspectives for ecological complexity. University of Chicago Press, Chicago, Illinois, USA.

Anderson, L. G. 2000. Selection of property rights management system. 2000. Pages 39-60 in R. Shotton, editor. Uses of property rights in fisheries management. FAO Technical Paper 404/2. FAO, Rome, Italy. [online] URL: http://www.fao.org/docrep/003/ x7579e/x7579e03.htm\#b3-Selection $\% 20$ of $\% 20 \mathrm{a} \% 20$ Property $\% 20$ Rights $\%$ 20Management $\% 20$ System $\% 20$ L. $\% 20$ G. \%20Anderson

Apollonio, S. 2002. Hierarchical perspectives on marine complexities: searching for systems in the Gulf of Maine. Columbia University Press, New York, New York, USA.

Apollonio, S., and J. Dykstra. 2008. An enormous, immensely complicated intervention: groundfish, the New England fishery management council, and the world fishery crisis. E-book Time, LLC., Montgomery, Alabama, USA.

Armstrong, C. W., and U. R. Sumaila. 2001. Optimum allocation of TAC and the implications of implementing an ITQ management system for the North-East Arctic cod. Land Economics 77:350-359. http://dx.doi.org/10.2307/3147129

Arnason, R. 2000. Property rights as a means of economic organization. Pages 14-25 in R. Shotton, editor. Uses of property rights in fisheries management. FAO Technical Paper 404/2. FAO, Rome, Italy. [online] URL: http://www.fao.org/docrep/003/ x 7579e/x7579e03.htm\#b2-Property $\% 20$ Rights $\% 20$ as $\% 20 \mathrm{a} \% 20$ Means $\%$ 20of $\% 20$ Economic $\% 20$ Organization $\% 20$ R. $\% 20$ Arnason

Arnason, R. 2005. Property rights in fisheries: Iceland's experience with ITQs. Reviews in Fish Biology and Fisheries 15:243-264. http://dx.doi.org/10.1007/s11160-005-5139-6 
Arnason, R. 2012. Property rights in fisheries: how much can individual transferable quotas accomplish? Review of Environmental Economics and Policy 6(2):217-236. http://dx.doi. org/10.1093/reep/res011

Berkeley, S. A., M. A. Hixon, R. J. Larson, and M. S. Love. 2004. Fisheries sustainability via protection of age structure and spatial distribution of fish populations. Fisheries 29(8):23-32. http://dx. doi.org/10.1577/1548-8446(2004)29[23:fsvpoa]2.0.co:2

Bernier, D. 1997. Beware the march toward fisheries privatization. Fisheries 22(3):30-31.

Beverton, R. 1998. Fish, fact, and fantasy: a long view. Reviews of Fish Biology and Fisheries 8:229-249. http://dx.doi.org/10.1023/ A: 1008888411100

Beverton, R., and S. Holt. 1957. On the dynamics of exploited fish populations. (2004 edition). Blackburn Press, Caldwell, New Jersey, USA.

Bolster, W. J. 2012. The mortal sea. Harvard University Press, Cambridge, Massachusetts, USA. http://dx.doi.org/10.4159/ $\underline{\text { harvard.9780674067219 }}$

Branch, T. A. 2009. How do individual transferable quotas affect marine ecosystems? Fish and Fisheries 10:39-57. http://dx.doi. org/10.1111/j.1467-2979.2008.00294.X

Brewer, J. F. 2011. Paper fish and policy conflict: catch shares and ecosystem-based management in Maine's groundfishery. Ecology and Society 16(1):15. [online] URL: http://www.ecologyandsociety. org/vol16/iss1/art15/

Bromley, D. W. 2009. Abdicating responsibility: the deceits of fisheries policy. Fisheries 34(6):280-290. http://dx.doi. org/10.1577/1548-8446-34.6.280

Cabral, R. B., and P. M. Aliño. 2011. Transition from common to private coasts: consequences of privatization of the coastal commons. Ocean and Coastal Management 54:66-74. http://dx. doi.org/10.1016/j.ocecoaman.2010.10.023

Christy, F. T. 1973. Fisherman quotas: a tentative suggestion for domestic management. Occasional Paper no. 19. Law of the Sea Institute, University of Rhode Island, Kingston, Rhode Island, USA.

Chu, C. 2009. Thirty years later: the global growth of IATAQs and their influence on stock status in marine fisheries. Fish and Fisheries 10:217-230. http://dx.doi.org/10.1111/j.1467-2979.2008.00313. $\underline{\mathrm{X}}$

Clay, P., P. Pinto da Silva, and A. Kitts. 2010. Defining social and economic performance measures for catch share systems in the Northeast U.S. Proceedings of the Fifteenth Biennial Conference of the International Institute of Fisheries Economics \& Trade, July 13-16, Montpellier, France: Economics of Fish Resources and Aquatic Ecosystems: Balancing Uses, Balancing Costs. Compiled by A. L. Shriver. International Institute of Fisheries Economics \& Trade, Corvallis, Oregon, USA. [online] URL: http://ir.library. oregonstate.edu/xmlui/bitstream/handle/1957/39119/338.pdf? sequence=1

Copes, P. 2000. Adverse impacts of individual quota systems on conservation and fish harvest productivity. Keynote address presented at Eighth Biennial Conference of the International Institute of Fisheries Economics and Trade, Marrakech,
Morocco. Discussion Paper 00-2, Institute of Fisheries Analysis, Simon Fraser University, Burnaby, British Columbia, Canada. [online] URL: http://oregonstate.edu/dept/IIFET/copes morocco. pdf

Copes, P., and A. Charles. 2004. Socioeconomics of individual transferable quotas and community based fishery management. Agricultural and Resource Economics Review 33(2):171-181.

Costello, C., S. D. Gaines, and J. Lyman. 2008. Can catch shares prevent fisheries collapse? Science 321:1678-1681. http://dx.doi. org/10.1126/science. 1159478

Costello, C., J. Lyman, S. E. Lester, and S. D. Gaines. 2010. Economic incentives and global fisheries sustainability. Annual Review of Resource Economics 2:299-318. http://dx.doi. org/10.1146/annurev.resource.012809.103923

Criddle, K. R., and S. Macinko. 2000. A requiem for the IFQ in US fisheries. Marine Policy 24:461-469. http://dx.doi. org/10.1016/S0308-597X(00)00025-7

Cushing, D. H. 1977. The problems of stock recruitment. Pages 116-133 in J. A. Gulland, editor. Fish population dynamics. John Wiley, London, UK.

Ecotrust Canada. 2009. A cautionary tale about ITQ fisheries. Ecotrust Canada, Vancouver, British Columbia, Canada. [online] URL: http://ecotrust.ca/briefing/a-cautionary-tale-about-itq-fisheries/

Essington, T. E. 2010. Ecological indicators display reduced variation in North American catch share fisheries. Proceedings of the National Academy of Sciences 107(7):754-759. http://dx.doi. org/10.1073/pnas.0907252107

Essington, T. E., M. C. Melnychuk, T. A. Branch, S. S. Heppell, O. P. Jensen, J. S. Link, S. J. D. Martell, A. M. Parma, J. G. Pope, and A. D. M. Smith. 2012. Catch shares, fisheries, and ecological stewardship: a comparative analysis of resource responses to rights-based policy instrument. Conservation Letters 5:186-195. http://dx.doi.org/10.1111/j.1755-263X.2012.00226.x

Eythórsson, E. 2000. A decade of ITQ management in Icelandic fisheries: consolidation without consensus. Marine Policy 24:483-492. http://dx.doi.org/10.1016/S0308-597X(00)00021-X

Finley, C. 2011. All the fish in the sea: maximum sustainable yield and the failure of fisheries management. University of Chicago Press, Chicago, Illinois, USA. http://dx.doi.org/10.7208/ chicago/9780226249681.001.0001

Frank, K. T., and D. Brickman. 2000. Allee effect and compensatory population dynamics within a stock complex. Canadian Journal of Fisheries and Aquatic Sciences 57:513-517. http://dx.doi.org/10.1139/f00-024

Gibbs, M. 2010. Why ITQs on target species are inefficient at achieving ecosystem based fisheries management outcomes. Marine Policy 34:708-709. http://dx.doi.org/10.1016/j.marpol.2009.09.005

Hayden, A., J. Acheson, M. Kersula, and J. Wilson. 2015. Spatial and temporal pattern in the cod fisheries of the North Atlantic. Conservation and Society, in press.

Hilborn, R., and U. Hilborn 2012. Overfishing: what everyone needs to know. Oxford University Press, New York, New York, USA. 
Holland, D. 2000. Fencing the fisheries commons: regulatory barbed wire in the Alaskan groundfish fisheries. Marine Resource Economics 17:141-149.

Huggins, L. E. 2011. Fencing fisheries in Namibia and beyond: lessons from the developing world. PERC Policy Series. Property and Environment Research Center, Bozeman, Montana, USA.

Leal, D., M. De Alessi, and P. Baker. 2006. Governing U.S. fisheries with IFQs. Property and Environment Research Center, Bozeman, Montana, USA.

Longhurst, A. 2010. The mismanagement of marine fisheries. Cambridge University Press, Cambridge, UK. http://dx.doi. org/10.1017/cbo9781139195928

McCay, B. 2004. ITQ and community: an essay on environmental governance. Agricultural and Resource Economics Review 33 (2):162-170.

McCay, B. J, C. F. Creed, A. C. Finlayson, R. Apostle, and K. Mikalsen. 1995. Individual transferable quotas (ITQs) in Canadian and US fisheries. Ocean and Coastal Management 28 (1-3):85-115. http://dx.doi.org/10.1016/0964-5691(95)00068-2

Munro, G., N. Bingham, and E. Pikitch. 1998. Individual transferable quotas, community-based fisheries management systems and "virtual" communities. Fisheries 25(3):12-15.

Nowlis, J., and A. A. Van Benthem. 2012. Do property rights lead to sustainable catch increases? Marine Resource Economics 27 (1):89-105. http://dx.doi.org/10.5950/0738-1360-27.1.89

Olson, J. 2011. Understanding and contextualizing social impacts from the privatization of fisheries: an overview. Ocean and Coastal Management 54:353-363. http://dx.doi.org/10.1016/j. ocecoaman.2011.02.002

O’Neill, R. V., D. L. DeAngelis, J. B. Waide, and T. F. H. Allen. 1986. A hierarchical concept of ecosystems. Princeton University Press, Princeton, New Jersey.

Palsson, G., and G. Pétursdóttir, editors. 1997. Social implications of quota systems in fisheries. Nordic Council of Ministers, Copenhagen, Denmark.

Pauly, D. 1996. ITQ: The assumptions behind the meme. Reviews in Fish Biology and Fisheries 6:109-112. http://dx.doi.org/10.1007/ $\underline{\mathrm{BF} 00058523}$

Pianka, E. R. 1970. On r- and K-selection. American Naturalist 104:592-597. http://dx.doi.org/10.1086/282697

Pinkerton, E., and D. N. Edwards. 2009. The elephant in the room: the hidden costs of leasing individual transferable quotas. Marine Policy 33:707-713. http://dx.doi.org/10.1016/j.marpol.2009.02.004

Rose, G. 2007. Cod: the ecological history of the North Atlantic fisheries. Breakwater Books, St. John's, Newfoundland, Canada.

Salz, P. 1996. ITQs in the Netherlands: twenty years of experience. ICES C.M., International Council for the Exploration of the Sea, Copenhagen, Denmark. [online] URL: http://www.framian.nl/ includes/download.asp?file id=225

Sanchirico, J., and R. Newell. 2003. Catching market efficiencies: quota-based fisheries management. Resources 150:8-11. [online]
URL: http://www.rff.org/research/publications/catching-marketefficiencies-quota-based-fisheries-management

Sissenwine, M. P. 1974. Variability in recruitment and equilibrium catch of the southern New England yellowtail flounder fishery. Journal du Conseil International pour l'Exploration de la Mer 36 (1):15-26. http://dx.doi.org/10.1093/icesims/36.1.15

Soliman, A. 2014. Individual transferable quotas in world fisheries: addressing legal and rights-based issues. Ocean and Coastal Management 87:102-113. http://dx.doi.org/10.1016/j. ocecoaman.2013.09.012

Spilhaus, A. 1963. Oceanography's future. U.S. Naval Institute Proceedings. Nov.:26-37.

Squires, D., H. Campbell, S. Cunningham, C. Dewees, R. Q. Grafton, S. F. Herrick Jr, J. Kirkley, S. Pascoe, K. Salvanes, B. Shallard, B. Turris, and N. Vestergaard. 1998. Individual transferable quotas in multispecies fisheries. Marine Policy 22 (2):135-159. http://dx.doi.org/10.1016/s0308-597x(97)00039-0

Sumaila, U. R. 2010. A cautionary note on individual transferable quotas. Ecology and Society 15(3):36.

Swartz, W., E. Sala, S. Tracy, R. Watson, and D. Pauly. 2010. The spatial expansion and ecological footprint of fisheries (1950 to the present). PLOS ONE 5:e15143. http://dx.doi.org/10.1371/ journal.pone.0015143

Thébaud, O., J. Innes, and N. Ellis. 2012. From anecdotes to scientific evidence: a review of the recent literature on catch shares systems in marine fisheries. Frontiers in Ecology and the Environment 10(2):433-437. http://dx.doi.org/10.1890/110238

Walters, C., and P. Pearce 1996. Stock information requirements for quota management systems in commercial fisheries. Reviews in Fish Biology and Fisheries 6:21-42. http://dx.doi.org/10.1007/ $\underline{\mathrm{BF} 00058518}$

Wieland, R. 1992. Why people catch too many fish: a discussion of economic incentives. Center for Marine Conservation, Washington, D.C., USA.

Wilson, J. A. 2006. Matching social and ecological systems in complex ocean fisheries. Ecology and Society 11(1):9. [online] URL: http://www.ecologyandsociety.org/vol11/iss1/art9

Wingard, J. 2000. Community transferable quotas: internalizing externalities and minimizing social impacts of fisheries management. Human Organization 59(1):48-57. http://dx.doi. org/10.17730/humo.59.1.h72h254mw34v0700

Worm, B., R. Hilborn, J. K. Baum, T. A. Branch, J. S. Collie, C. Costello, M. J. Fogarty, E. A. Fulton, J. A. Hutchings, S. Jennings, O. P. Jensen, H. K. Lotze, P. M. Mace, T. R. McClanahan, C. Minto, S. R. Palumbi, A. M. Parma, D. Ricard, A. A. Rosenberg, R. Watson, and D. Zeller. 2009. Rebuilding global fisheries. Science 325:578-584. http://dx.doi.org/10.1126/science.1173146

Yandle, T., and C. M. Dewees. 2008. Consolidation in an individual transferable quota regime: lessons from New Zealand, 1986-1999. Environmental Management: 41:915-928. http://dx. doi.org/10.1007/s00267-008-9081-y 